Ann. Zootech., 1980, 29, no h. s., 325-336.

\title{
Enzymatic methods to predict the value of the energy and protein in feedingstuffs
}

\author{
D.F. OSBOURN and R.C. SIDDONS \\ The Grassland Research Institute, \\ Hurley, Maidenhead, Berkshire, SL6 5LR, UK.
}

\begin{abstract}
Research into the use of enzymatic procedures to predict the energy and protein value of feeds for cattle is reviewed. Satisfactory methods for the empirical prediction of the potential organic matter digestibility of feedstuffs using the cellulolytic activity of rumen liquor both in vivo and in vitro and fungal cellulase preparations in vitro have been developed and correlated with direct animal determinations. Similar techniques have been examined as a basis for estimating the potential degradability in the rumen of the protein in feedstuffs but there is a lack of precise animal data against which to validate these methods. These methods have been widely used in research work and are generally more precise than chemical methods, but are too costly for the routine advisory assays. In both fields enzymatic studies of rates of hydrolysis seem to be revealing the need to develop simpler methods to partition both the cell wall and total $\mathrm{N}$ fractions into at least three distinct parts based on their rate of hydrolysis. If this were possible then not only the potential degradation but also the likely deviations from potential occuring in vivo might be predicted.
\end{abstract}

\section{Résumé}

\section{Méthodes enzymatiques de prédiction de la valeur énergétique et azotée des aliments}

L'auteur présente une revue des travaux de recherches réalisés sur l'utilisation des méthodes enzymatiques pour prédire la valeur énergétique et azotée des aliments pour les bovins. Des méthodes satisfaisantes ont été mises au point et reliées aux mesures directes sur l'animal ; elles permettent de prédire empiriquement la digestibilité potentielle de la matière organique des aliments, en utilisant l'activité cellulolytique du jus de rumen à la f'ois in vivo et in vitro et des préparations de cellulose fongique in vitro. Des techniques similaires ont été étudiées dans le but d'estimer sur les aliments la dégradabilité potentielle des matières azotées des aliments dans le rumen, mais il manque des données correspondantes précises sur animaux permettant de vérifier ces méthodes.

Ces méthodes ont été largement utilisées dans les travaux de recherches et sont généralement plus précises que les méthodes chimiques mais elle coûtent trop cher pour être utilisées en série dans les laboratoires de contrôles. 
Les études enzymatiques sur les vitesses d'hydrolyses semblent mettre en évidence la nécessité de mettre au point des méthodes plus simples pour séparer aussi bien les membranes cellulaires ou les constituants azotés au moins en trois fractions distinctes fonction de leur vitesse d'hydrolyse. Si cela était possible, on pourrait alors prédire, non seulement la dégradation potentielle, mais aussi les écarts qui peuvent se produire in vivo par rapport à ce potentiel.

\section{Introduction}

The major source of variation in the energy made available to cattle for maintenance and production is the variation found in the availability of the organic matter to enzymic digestion; or more particularly the availability of the cell wall fraction in forages to the cellulolytic enzymes secreted by the micro-organisms in the rumen.

There is an equal variation in the apparent digestibility of crude protein in feedstuffs but, because of the synthesis of microbial protein that occurs in the rumen, this apparent digestibility bears little relationship to the protein or amino acids absorbed. These are theoretically estimated as the sum of the dietary protein undegraded in the rumen and the microbial protein leaving the rumen and digested in the small intestine. All these processes are dependent upon enzymatic hydrolyses. It is not therefore surprising that enzymatic laboratory procedures have been used to seek both an empirical solution of the potential availability of energy and protein in feedstuffs as well as an understanding of the mechanisms involved.

\section{Estimation of the energy value of feeds}

Laboratory methods of estimating the energy value of feeds have in general been correlated with in vivo determinations of the digestibility of dry matter (DMD) or organic matter (OMD) made with mature sheep often at a maintenance level of feeding. The estimation of the digestible, metabolisable or the various net energy values from laboratory procedures rely upon relationships with DMD or OMD developed from in vivo observations. The major problem has been to estimate the digestibility of the structural carbohydrates in forage feeds. The various methods proposed nearly all depend upon gravimetric estimates of the feed residues after exposure to the enzymes and may be divided into three groups on the basis of the technique adopted to expose the forage to the action of structural polysaccharidases and the source of these enzymes.

\section{Methods based on in vivo exposure to rumen micro-organisms}

In 1938 Quin et al. used silk bags to expose feeds to the enzymes present in the rumen and measure the extent of digestion. Nylon and dacron bags were subsequently introduced; their use has been reviewed by LOWREY (1970). Originally the method was difficult to standardise and the correlations obtained with 
animal data were very limited, but in 1970 CHENOST et al. showed that incubation of the residues from nylon bags with acidified pepsin improved reliability giving a standard error of the estimate of 3.6 percentage units in a study on 83 forage samples. More recently AERTs et al. (1977) have found the nylon bag technique to be subject to lower errors than both chemical and in vitro procedures. The residual standard deviation of the regression of in vivo on nylon bag estimates of OMD for 42 hay samples was \pm 2.4 per cent, the corresponding value for silages was 5.6 per cent.

\section{Methods based on in vitro exposure to rumen micro-organisms}

The incubation of dried ground herbage samples with rumen micro-organisms and buffer solutions in anaerobic conditions in glass tubes was reported by Asplund et al. (1958). Hershberger et al. (1959) used a similar one stage in vitro procedure to predict cellulose digestion on 35 feed samples with an error of estimation of \pm 2.0 units. However, inter-laboratory studies reported by BARNES (1968) revealed considerable variation between laboratories for both 24 and 48 hour incubations. TILley et al. (1960) demonstrated that the error of estimation of DMD of 4.4 units achieved with a single stage 48 hour in vitro digestion was reduced by 2.0 by the introduction of a second 48 hour incubation with pepsin. Repeatability of this technique in 19 laboratories was good, producing an average residual standard deviation of \pm 2.5 digestibility units (BARNES, 1970).

However, DEN BRAVER and ERIKSSON (1967) discovered that a single stage method could be made much more precise $\left(S_{y \cdot x} \mathrm{ODM}= \pm 2.37\right.$ for 108 hay, clover and grass samples) if the incubation was extended to $96 \mathrm{~h}$ and only one $\mathrm{ml}$ of fresh rumen fluid and $50 \mathrm{ml}$ of buffer solution were added to $0.5 \mathrm{~g}$ sample of hay. Further study of this "Rumen Digestible Organic Matter" method revealed that rumen liquor frozen at $-80^{\circ} \mathrm{C}$ could be stored for long periods without change in activity when used in this way and that the method was highly repeatable between laboratories (DEN BRAVER, 1977).

Nevertheless despite its many disadvantages, the two-stage in vitro digestion procedure described by TILLEY and TERRY (1963) has been the method most widely used in laboratories throughout the world. The basic procedure has been modified to simplify the equipment required (ALEXANDER and McGowan, 1961 ; Dent, 1963 ; Rogers and Whitmore, 1966 ; LilA, 1977), and streamlined and standardised to examine large numbers of samples routinely (ALEXANDER and McGowan, 1966 ; Minson and McLeod, 1972 ; Newman, 1972).

Annotated bibliographies of the literature appertaining to in vitro procedures have been prepared by VAN DYNE and HaUg (1968) and the CommonwealtH Bureau of Pasture and Field Crops (1979), and reviewed in some depth by Barnes (1973) and Osbourn and Terry (1977).

Numerous authors have examined the error of prediction of DMD or OMD from the estimates made by the two-stage procedure and have found the residual standard deviation to be of the order of $2.0-3.0$ digestibility units or less on a wide range of herbages and forage crops (TIlley and TERrY, 1963; ADEMOSUM et al., 1968 ; Deinum et al., 1968 ; Deinum and VAn SoESt, 1969; Van Ver Koelen and Dijkstra, 1971 ; Nehring, 1971 ; Minson and McLeod, 1972 ; VAn Der Koelen and VAN Es, 1973 ; Terry et al., 1974 ; Kellner and KirchgeSSNER, 1976a, O'SheA, 1977; Tsutsumi and ABE, 1977). In general these studies have shown that the two-stage procedure estimates digestibility with a lower error 
than the Weende or summative methods of chemical analysis although the work of WitT and Pedersen (1975) is an exception to this generalisation. There is some dispute as to the validity of one regression relationship for all types of forages which has been resolved by the use of standards of the same species by Minson and McLeod (1972) or separate regression for different classes of feeds (VAN Der Koelen and DiJKSTRA, 1971). In addition, cellulolytic activity can vary from week to week necessitating the correction of observations relative to standards.

While the method is of particular value for the investigation of the variation in digestibility in new and unknown feeds, for the selection of breeding materials and the exploration of seosonal changes, chemical determinations of fibre fractions remain the basis of most routine advisory services because of their simplicity and relatively low cost.

\section{In vitro methods using fungal enzyme preparations and cellulolytic activity}

DoEfer et al., (1963) were amongst the earliest to examine the use of cellulase preparations to predict forage digestibility. JARRIGE et al. (1970), JONES and HAYWARD (1973) and HARTLEY et al., (1974), all related the disappearance of plant constituents resulting from incubation with cellulase preparations to the digestibility of the forages determined with sheep. For grasses, high correlations were obtained by both JONES and HAYwARD (1973) and HaRTLEY et al. (1974). The latter authors were also able to predict DMD with an error of \pm 1.65 units from the optical density at $324 \mathrm{~nm}$ of the filtrate from the cellulase digestion, thereby eliminating the need to dry and weigh the residue and its container.

As in the earlier work using rumen liquor, research has shown that pretreatment of herbage samples with pepsin (JONES and HAYWARD, 1975; GoTO and Minson, 1977) or neutral detergent (McQueEn and VAN SOEST, 1973 ; HarTley et al., 1974) improved the error of prediction of digestibility considerably, to values similar to those obtained with the two-stage in vitro procedure. CLARK and BEARD (1977) examined the use of amylase and pepsin in conjuction with cellulases and demonstrated their value for the estimation of the digestibility of rations containing cereal grains.

Techniques based upon fungal cellulases have consistently shown less variation between duplicates and between runs than techniques utilising rumen liquor (CLARK and BEARD, 1977). Separate regression equations are necessary for grasses and legumes using the pepsin/cellulase procedure (TERRY et al., 1978). The proportion of the organic matter solubilised by pepsin/cellulase techniques can be increased to the levels achieved in vivo by pre-treatment of the samples with $2 \mathrm{~N} \mathrm{HCl}$ at $100^{\circ} \mathrm{C}$ for $30 \mathrm{~min}$ (KELLNER and KIRCHGESSNER, 1976b) or by increasing the acidity and temperature of the pepsin incubation (ALISON and BORZUCKI, 1978).

The prediction of the digestible energy or calculated metabolisable or net energy of forages from estimates of OMD using rumen liquor and pepsin (TERRY et al., 1974) or pre-treated pepsin/cellulase (KELLNER and KirCHGESSNER, 1977) was improved by the inclusion of estimates of the crude protein or lipid contents of the feeds. Den Braver (1977) could find no evidence to support this when he related $\mathrm{ME}$ to DOM digested by rumen liquor.

The precision and ease with which enzyme preparations can be used has led to renewed interest in studies of the kinetics of cell wall hydrolysis. MERTENS (1973) and ABE and HoRII (1974) have demonstrated that two fractions, one 
rapidly digested and the other only slowly digested, are present within the potentially digestible fraction of forage cell walls. These two fractions together with the concept of a potentially indigestible cell wall fraction (WILKINS, 1968) form the basis of most modelling approaches to cell wall digestion. Techniques, be they enzymatic or physico-chemical, which could be used to define these three fractions, are urgently required.

\section{Estimation of the protein value of feeds}

Although the digestible $\mathrm{N}$ content of forages has been found to be highly correlated with the $\mathrm{N}$ solubilised on incubation with pepsin (GoERING et al., 1972), it is unlikely, because of the metabolic transformations that dietary $\mathrm{N}$ undergoes within the rumen, that the protein value of ruminant feeds can be assessed, as is the case for monogastric animals, from the protein content of the feed together with some measure of the digestibility of the protein. Both the non protein (NPN) and protein-N fractions of ruminant feeds are degraded by microbial enzymes in the rumen and while the degradation of the NPN is generally assumed to be complete, the extent to which protein is degraded varies between feeds. Ammonia is the main end product of the degradative process and, together with amino acids produced as intermediates of protein breakdown, serves as the $\mathrm{N}$ substrate for microbial growth. The undegraded dietary protein and ruminally synthesised microbial protein pass out of the rumen and are subjected to host enzyme digestion in the abomasum and small intestune. In vivo studies with re-entrant cannulated animals have shown that the amino acid composition of digesta entering the small intestine and the apparent digestibility of protein in the small intestine (70 per cent) are relatively constant over a wide range of diets. However, it has not been possible to establish any general relationships between the amount of protein entering the small intestine and dietary intake. It would appear therefore that the protein evaluation of ruminant feeds is dependent on the development of procedures for predicting both feed protein degradability and microbial protein synthesis.

\section{Prediction of feed protein degradability}

The extent to which dietary protein is degraded in the rumen determines the amount of feed protein which reaches the small intestine and also the ability of the diet meet microbial $N$ requirements. An insufficiency of ruminally available $\mathrm{N}$ will result in a reduction in microbial growth and consequently a reduction in fibre digestion and DM intake. In fact a distinction should be made between $\mathrm{N}$ degradability and protein degradability, but in most studies only the degradability of $\mathrm{N}$ has been measured.

\section{In vitro ammonia production}

Net ammonia production after the in vitro incubation of feed and rumen fluid has been widely used as a method for assessing $\mathrm{N}$ degradability. HenDrICKx and MARTIN (1969) used this technique with a series of purified proteins and found that the degradability was highly correlated with solubility in mineral buffer. For 
natural feedstuffs, however, there was no consistent relationship between ammonia production and $\mathrm{N}$ solubility (LitTLE et al., 1963, and Crookes et al., 1978), and the latter authors concluded that ammonia concentration during static incubation of natural feedstuffs does not reflect necessarily the rate of degradation of the protein fractions. However, the method would appear to be of value for assessing the relative effectiveness of treatments which reduce the degradability of the $\mathrm{N}$ fraction of the feed without affecting energy availability. For example, many workers have shown a reduction in in vitro ammonia production (and $\mathrm{N}$ solubility) as a result of treatment with heat or formaldehyde (AMos et al., 1976; Dinius et al., 1974, and BRODERICK and LANE, 1978). The use of net ammonia production as an index of ruminal protein degradability is complicated by the fact that it is the resultant of both degradative release and microbial uptake. The latter is energy dependent and consequently the comparison of feeds supplying different amounts of available energy is questionable. BorCHERs (1966) attempted to overcome this problem by the inclusion of thymol, an inhibitor of ammonia utilisation and amino acid deamination, in the incubation medium. Using the concentration of amino acids and ammonia as a measure of degradability, he found that although casein was rapidly degraded, the increase in degradation end products for natural feeds was not significantly different from the blank. Although the use of an inhibitor of $\mathrm{NH}_{3}$ re-utilisation may allow the "true" production of ammonia to be measured, it does not allow a distinction to be made between $\mathrm{NH}_{3}$ arising from feed $\mathrm{N}$ degradation and that from the degradation of microbial material. The extent of the latter will vary according to substrate availability and it is not uncommon to find that net ammonia production in the test incubation containing feed is lower than that in the blank. In addition, measurement of ammonia production does not take into account the direct incorporation by the micro-organisms of amino acids produced during the breakdown of feed protein. Therefore in order to obtain more meaningful results from the use of net ammonia production as an index of feed $\mathbf{N}$ degradation it is necessary to measure the amount of microbial $\mathrm{N}$ present at the end of the incubation. Feed $\mathrm{N}$ degraded will then equal the sum of these two fractions in the test incubation less their sum in the blank.

An alternative approach is to measure the amount of feed $\mathrm{N}$ remaining undegraded after incubation with rumen fluid. Using low speed centrifugation (3900 g) to separate undigested feed (sediment) from the microbial and digested material, MOLLER and THOMSEN (1977) showed that treatment of soyabean meal with formaldehyde reduced $N$ degradability. HARTNELL and SATTER (1978) used the tungstic acid precipitable $\mathrm{N}$ as a measure of microbial plus undegraded feed $\mathrm{N}$ flowing out of a continuous fermentor and after making various assumptions regarding the degradability of the $\mathrm{N}$ of alfalfa (also present in the fermentor) and the amount of microbial growth, they calculated that treatment of soyabean with masonex resulted in 15 per cent more protein escaping degradation.

\section{Protein degradation in nylon bags suspended in the rumen}

The disappearance of the components of a feed when (contained in small pore nylon bags) suspended in the rumen has long been recognised as a potential method of assessing DM, cellulose and fibre digestibility, but it is only relatively recently that the procedure has been applied to the study of $\mathrm{N}$ digestibility (Bailey and Hironka, 1970). Schoeman et al. (1972) used the technique for evaluating the effect of heat and formaldehyde on the degradability 
of protein supplements and also the effect basal diet on degradability. Subsequently detailed studies of the effect on $\mathrm{N}$ degradation of factors such as bag size and porosity, sample size and preparation etc. have been undertaken and standardised procedures proposed (Mehrez and OrSkov, 1977 ; VAN Hellen and Ellis, 1977 ; and Playne et al., 1978). By incubating the feed in the rumen for varying lengths of time it is possible to obtain time curves for $\mathrm{N}$ disappearance and thus the rate of $\mathrm{N}$ degradation. In the studies of MoHAmED and SMITH (1977) the rate of degradation of protein concentrates was examined, the curves were biphasic with a rapid degradation occurring between 0 and $2 \mathrm{~h}$ followed by a slower rate of degradation. Similar curves were obtained by CRAWFORD et al. (1978) for the degradation of the $\mathrm{N}$ in concentrates, hays and silages. For the concentrates and silages, $\mathrm{N}$ solubility in mineral buffer was significantly correlated with $\mathrm{N}$ disappearance after $2 \mathrm{~h}$ incubation in the rumen whereas with hays the $2 \mathrm{~h}$ disappearance was not significantly correlated with solubility but the disappearance after $4 \mathrm{~h}$ incubation was.

Although the method is sensitive to the conditions of measurement, which can be overcome by using a standardised procedure, and is subject to various criticisms such as nitrogenous material passing out of the bag need not necessarily be degraded to $\mathrm{NH}_{3}$ and the possible contamination of the residue in the bags with micro-organism or particulate matter which has entered the bag, it offers a relatively simple method for comparing the rate and potential maximum extent of degradation in the rumen of the $\mathbf{N}$ fraction of different feeds. MATHERs et al. (1977) found that for a series of protein supplements, $\mathrm{N}$ disappearance after $6 \mathrm{~h}$ incubation most closely reflected in vivo estimates of degradability. ORSKOV and MeHREZ (1977) measured both $\mathrm{N}$ and DM disappearance and estimated the extent of $\mathrm{N}$ degradation in the rumen as the $\mathrm{N}$ loss occurring when 90 per cent of the digestible DM had disappeared.

The extent of degradation in the rumen is a function of the rate of degradation and outflow rate from the rumen. Orskov and McDonald (1979) measured in sheep given a dried grass diet, the degradation rate of soyabean meal using the dacron bag procedure and the outflow rate by following the disappearance of chromium from the rumen after the intra-ruminal infusion of chromium-treated soyabean, which was resistant to microbial attack. At a restricted level of feeding the calculated degradability of the soyabean $\mathrm{N}$ was 71 per cent whereas with ad libitum feeding which induced a faster passage rate the calculated degradability was 66 per cent.

\section{In vitro studies using proteolytic enzymes}

The possibility that digestion with proteolytic enzymes might provide a means of predicting $\mathrm{N}$ degradability is suggested by the study of PICHARD and VAN SoEST (1977). They categorised the $\mathrm{N}$ of ruminant feeds into three fractions ; a water soluble non protein nitrogen fraction, a potentially degradable fraction and an undegradable fraction. The potentially degradable fraction consisted of 2 or more fractions differing in their rate of breakdown by proteolytic enzymes. The more rapidly degradable fraction together with the water soluble NPN fraction would presumably be completely degraded in the rumen while the extent of degradation of the other fraction (s) would be dependent on outflow rate from the rumen. 
Of the methods available for assessing $\mathrm{N}$ degradability, the nylon bag procedure would appear to be the method of choice. At present best estimates of extent of degradation would appear to be $\mathrm{N}$ loss after $6 \mathrm{~h}$ incubation for protein supplements and $\mathrm{N}$ loss when 90 per cent of the digestible DM had disappeared for other feeds. The ammonia production method is easier and quicker but its use is limited to the evaluation of treatments which specifically alter $\mathrm{N}$ degradability. The use of proteolytic enzymes may offer a simple alternative to the nylon bag procedure and warrants further investigation.

\section{Prediction of microbial protein synthesis in the rumen}

The measurement of microbial protein synthesis when feed and rumen fluid are incubated in vitro is unlikely to be of much value as a predictor of in vivo microbial protein synthesis because of the very different conditions obtained in the rumen and in a static incubation. These problems may be overcome by the use of continuous fermentors (SATTER and SLYTER, 1974) but at present the most reliable estimate of microbial protein synthesis is obtained from the rumen degradable $\mathrm{N}$ content and the DOM content of the feed. The former can be determined by the nylon bag procedure and the latter by in vitro digestibility or cellulase digestion as discussed earlier. It is then necessary to make a number of assumptions as discussed by Roy et al. (1977) i.e. rumen microbes require $19.5 \mathrm{~g}$ rumen degradable $\mathrm{N}$ per $\mathrm{kg}$ DOM, rumen degradable $\mathrm{N}$ is used by the microbes with an efficiency of 1.0 (urea 0.8 ) and 80 per cent of microbial $N$ is in the form of protein $\mathrm{N}$. As the authors point out, results in the literature show considerable variation about these mean values, but consider them the best estimates presently available. If the diet contains adequate rumen degradable $\mathrm{N}$ to meet microbial requirements $(>19.5 \mathrm{~g} / \mathrm{kg}$ DOM) then the amount of microbial protein synthesis will equal DOM intake $\times 19.5 \times 0.8$. If the diet is deficient in rumen degradable $\mathrm{N}$ then microbial protein synthesis will equal rumen degradable $\mathrm{N}$ intake $\times 0.8$. The sum of the predicted microbial protein and undegraded dietary protein multiplied by the coefficient of digestibility in the small intestine gives the amount of protein supplied to the animal by the diet. RoY et al. (1977) suggested using an apparent small intestine digestibility coefficient of 0.70 whereas KAUFMANN (1977) proposes the use of a true digestibility coefficient of 0.85 .

\section{Conclusion}

It is relatively simple to determine the indigestible residue of plant cell walls following hydrolysis in vivo or in vitro. There is a large body of animal data against which to correlate laboratory studies. Furthermore as there are two sites of cell wall digestion in the animal the deviations occurring in the animal from the potential digestibility measured in the laboratory are generally small. In contrast the concept of dietary protein degradability in the rumen is largely theoretical and there are few accurate in vivo determinations of either degradability or the net synthesis of microbial protein in the rumen. As digestion and absorption of amino accids occurs at only one site in the animal, it seems probable that greater deviations from potential degradability may well occcur. 
The enzymatic techniques used to estimate the energy and protein value of feeds have been very similar. It is interesting to note that in both areas research is currently concerned with the kinetics of rate of digestion and it seems that out of this may come simpler methods of describing feedstuffs that will allow not only prediction of their potential value but also their actual value in real situations.

\section{References}

ABE A., Horit S., 1974. Cellulase hydrolysis of the cell wall and its application to the estimation of the nutritive value of forage. J. Jap. Soc. Grassld. Sci., 20, 16-21.

Aerts J.V., de Brabander D.L., Cottyn B.G., Buysse F.X., 1977. Comparison of laboratory methods for predicting the organic matter digestibility of forages. Feed' Sci. Technol. 2, 337-349.

Ademosum A.A., Baumgardt B.R., Scholl J.M., 1968. Evaluation of Sorghum - Sudangrass Hybrid at varying stages of maturity on the basis of intake digestibility and chemical composition. J. Anim. Sci., 27, 818-823.

Alexander R.H., MCGowan M., 1961. A filtration procedure for the in vitro determination of digestibility of herbage. J. Brit. Grassld. Soc., 16, 275-276.

Alexander R.H., MCGowan M., 1966. The routine determination of in vitro digestibility of organic matter in forage. An investigation of the problems associated with continuous large scale operation. J. Brit. Grassld. Soc., 21, 140-147.

Alison M., Borzucki R., 1978. Cellulase methods for the efficient digestion of grasses and brassicas. J. Sci. Fd. Agric. 29, 293-297.

Amos H.E., Evans J., Brudick D., Park T., 1976. Nitrogen balance and abomasal crude protein and amino acids in wethers fed formaldehyde treated Coastal Bermuda grass. $J$. Anim. Sci., 43, 1300.

Asplund J.M., Berg R.T., McElroy L.W., Pigden W.J., 1958. Dry matter loss and volatile fatty acid production in the artificial rumen as indices of forage quality. Can. J. Anim. Sci. 38, $171-180$.

Bailey C.B., Hironka R., 1970. Maximum loss of food from nylon bags in the rumens of steers as related to apparent digestibility. Can. J. Anim. Sci. 50, 325.

BARNES R.F., 1968. Variability within and among stations in the determination of in vivo digestibility and intake of alfalfa. J. Anim. Sci. 27, 519-524.

BARNES R.F., 1970. Collaborative research with the two stage in vitro rumen fermentation technique. Proceedings of the National Conference of Forage Quality Evaluation and Utilisation, 1969. Lincoln, Nebraska, pp. N1-N20.

BARNES R.F., 1973. Laboratory methods of evaluating feeding value in herbage. In Chemistry and Biochemistry of Herbage. Edit. Butler G.W. and Bailey R.W. Academic Press, London and New York, 3, Chap. 31, pp. 179-214.

Borchers R., 1965. Proteolytic activity of rumen in vitro. J. Anim. Sci., 24, 1033.

BRODERICK G.A., IAANE G.T., 1978. Lactationa1, in vitro and chemical evaluation of untreated and formaldehyde treated casein supplements. J. Dairy Sci. 61, 932.

Chenost M., Grenet E., Demarquilly C., Jarrige R., 1970. The use of nylon bag technique for the study of forage digestion in the rumen and for predicting feed intake. Proc. 11 th int. Grassld. Congr. Surfers Paradise 697-701.

Clarck J., Beard J., 1977. Prediction of the digestibility of ruminant feeds from their solubility in enzyme solutions. Anim. Fd. Sci. Technol. 2. 153-159.

Commonwealth Bureau of Pastures and Field Crops, 1979. Annotated Bibliography No. G498 Technique : Digestibility Determination 1969-78 Hurley, Maidenhead, Berks. SL6 5LR, UK.

Crawford Jr. R.J., Hoover W.H., Sniffen C.J., Crookes B.A., 1978. Degradation of feedstuff nitrogen in the rumen vs nitrogen solubility in three solvents. J. Anim. Sci. 46, 1768.

Crookes B.A., Sniffen C.J., Hoover W.H., Johson L.L., 1978. Solvents for soluble nitrogen measurements in feedstuffs. J. Dairy Sci. 61, 437. 
Deinum B., VAN Es A.J.H., VAN Soest P.J., 1968. Climate, nitrogen and grass 2. The influence of light intensity, temperature and nitrogen on in vivo digestibility of grass and the prediction of these effects from some chemical procedures. Neth. J. Agric. Sci. 16, 217-223.

Deinum B., Van Soest P.J., 1969. Prediction of forage digestibility from some laboratory procedures. Neth. J. agric. Sci. 17, 119-127.

Den BRAver E.J., 1977. The suitability of the RDOM-method to determine metabolisable energy in forages. European Association for Animal Production. 28th Annual Meeting 1977 Brussels. Paper presented to the Animal Nutritional Commission pp. 9.

Den BRaver E.J., ERIKSson S., 1967. Determination of the energy in grass hay by in vitro methods. Landibrakshogskolans Annaler 33, 761-765.

DENT J.W., 1963. Application of the two-stage in vitro digestibility method to variety testing. J. Brit. Grassid Soc. 18, 181-188.

Dinius D.A., Lyon C.K., Waler H.G., 1974. In vitro evaluations of protein and proteinsafflower oil complexes treated with formaldehyde. J. Anim. Sci. 38, 467.

Donefer E., Niemann P.J., Crampton E.W., Lloyd L.E., 1963. Dry matter disappearance by enzyme and aqueous solutions to predict nutritive value of forages. J. Dairy Sci. 46, 965-968.

Goering H.K., Gordon C.H., Hemken R.W., Waldo D.R., VaN Soest P.J., Smith L.W., 1972. Analytical estimates of $\mathrm{N}$ digestibility in heat damaged forages. J. Dairy Sci. 55, 1275.

Goto I., Minson D.J., 1977. Prediction of the dry matter digestibility of tropical grasses using a pepsin cellulase assay. Anim. Fd. Sci. Technol. 2, 247-253.

HaRTley R.D., Jones E.C., FEnlon J.S., 1974. Prediction of the digestibility of forages by treatment of their cell walls with cellulolytic enzymes. J. Sci. Fd. Agric. 25, 947-954.

Hartnell G.F., SatTer L.D., 1978. Effect of masonex (hemicellulose extract) on protein degradation by rumen micro-organisms in vitro and in vivo. J. Anim. Sci. 47, 935-943.

HENDRICKX H., MARTIN J., 1969. In vitro study of the nitrogen metabolism in the rumen. C.r. Rech. Inst. Encour. Rech. Scient. Ind. Agric. 31, 9.

Hershberger T.V., Long T.A., Hartsook E.W., Swift R.W., 1959. Use of artificial rumen techniques to estimate the nutritive value of forages. J. Anim. Sci. 18, 770-779.

Jarrige R., Thivend P., Demarquilly C., 1970. Development of cellulolytic enzyme digestion for predicting the nutritive value of forages. Proc. 11th int. Grassld Cong. 762-6.

Jones D.I.H., Hayward M.V., 1973. A cellulase digestion technique for predicting the dry matter digestibility of grasses. J. Sci. Fd Agric. 24, 1419-1426.

Jones D.I.H., HaYward M.V., 1975. The effect of pepsin pre-treatment of herbage in the prediction of dry matter digestibility from solubility in fungal cellulase. $J . S c i$. $F d$. Agric. 26, 711-718.

KaUFMANN W., 1977. Calculation of the protein requirement for dairy cows according to measurements of $\mathrm{N}$ metabolism. Proc. 2nd Int. Symp. on Protein Met. and Nutr. EAAP Public. No. $20: 130-132$.

Kellner R.J., KirChgessner M., 1976a. In vitro assessment of digestibility of fresh and coarse fodder. Wirtschaftseigens Futter 22, 157-167.

Kellner R.J., Kirchgessner M., 1976b. Zur Methodik der in vitro Verdaulichkirtsbestimmung von Grun und Rauhfutter mit Cellulase. Landwirtschaftliche Forschung 29 , 204-210.

Kellner R.J., Kirchgessner M., 1977. Estimation of forage digestibility by cellulase methods. Zeitschrift für Tierphysiologie, Tiernährung und Futtermittelkunde 39 (1), 9-16.

Lila M., 1977. Technique de mesure de la digestibilité in vitro en grande série en vue de la sélection pour la qualité des plantes fourragères. Ann. Amelior. Plantes 27 (1), 117-128.

Little C.O., Burroughs W., Woods W., 1963. Nutrional significance of soluble $\mathrm{N}$ in dietary proteins for ruminants. J. Anim. Sci. 22, 358.

Lowrey R.S., 1970. The nylon bag technique for the estimation of forage quality. Proceedings of the National Conference on Forage Quality, Evaluation and Utilisation (1969) Lincoln, Nebraska 01-012.

Mathers J.C., Horton C.M., Miller E.L., 1977. Rate and extent of protein degradation in the rumen. Proc. Nutr. Soc. 36, 37A.

MCQUeEN R.M., VAN SoEsT P.J., 1973. Evaluation of forage with cellulolytic enzymes from Trichoderma viridae. J. Dairy Sci. 56, 680-688. 
Mehrez A.Z., Orskov E.R., 1977. A study of the artificial fibre bag technique for determining te digestibility of feeds in the rumen. J. agric. Sci. (Camb.) 88, 645 .

Mohamed O.E., Smith R.H., 1977. Measurement of protein degradation in the rumen. Proc. Nutr. Soc. 36, 152A.

MERTENS D.R., 1973. Application of theoretical mathematical models to cell wall digestion and forage intake in ruminants. Ph.D. thesis, Cornell University.

Minson D.J., MCLeOT M.N., 1972. The in vitro technique, its modification for estimating digestibility of large numbers of tropical pasture samples. Technical Paper Division of Tropical Pastures CSIRO (1972) No. 815 pp.

Moller P.D., Thomsen K.V., 1977. Nitrogen utilisation from forages by ruminants. Laboratory and physiological measurements. Proc. NJF Seminar. Uppsala Init. fur Husdjuvens Utfodzing och vard Rapport No. 54, 27.

NEHRING K., 1971. Determination of the digestibility of feeding stuffs by in vitro techniques. I. Methodological studies. Archiv. für Tierernährung, 21, 659-684.

NewMan D.M.R., 1972. A modified procedure for large scale pasture evaluation by digestibility in vitro. J. Austral. Inst. agric. Sci. 38, 212-213.

Orskov E.R., MCDonald I., 1979. The estimation of protein degradability in the rumen from incubation measurements weighted according to rate of pasture. J. agric. Sci. (Camb.) 92, 499.

Orskov E.R., Mehrez A.Z., 1977. Estimation of extent of protein degradation from basal feeds in the rumen of sheep. Proc. Nutr. Soc. 36, 78A.

Osbourn D.F., TERry R.A., 1977. In vitro techniques for the evaluation of ruminant feeds. Proc. Nutr. Soc. 36, 219-225.

O'SHEA J., 1977. Evaluation of silage nutritive value by the in vitro digestibility procedure. Proceedings International meeting on animal production from temperate grassland, Dublin, June 1977.

Pichard G., Van Soest P.J., 1977. Protein solubility of ruminant feeds. Proc. Cornell Nutr. Conf. p. 91.

Playne M.J., Khumnualthong W., Echevarria M.G., 1978. Factors affecting the digestion of oesophageal fistula samples and hay samples in nylon bags in the rumen of cattle. J. agric. Sci. (Camb.) 90, 193.

Quin J.I., Van Der Wath J.G., Myburgh S., 1938. Studies in the alimentary tract of the Merino sheep in South Africa. IV. Description of experimental technique. Ondspt. $J$. vet. Sci. anim. Ind. 11, 341-387.

Rogers H.M., Whitmore E.T., 1966. Modified method for the determination in vitro of herbage digestibility in plant breeding studies. J. Brit. Grassld Soc. 21, 150-152.

Roy J.H.B., Balch C.C., Miller E.L., Orskov E.R., SMITH R.H., 1977. Proc. 2 nd Int. Symp. on Protein Metabolism and Nutrition. EAAP Public. No. 20, 126-129.

SAtTer L.D., Slyter I.L., 1974. Effect of ammonia concentration on rumen microbial protein production in vitro, Brit. J. Nutr. 32, 199.

Schoeman E.A., de Wet P.J., Burger W.J., 1972. The evaluation of the digestibility of treated proteins. Agroanimalia, 4, 35.

Terry R.A., Mundell D.C., Osbourn D.F., 1978. Comparison of two in vitro procedures using rumen liquor-pepsin or pepsin-cellulase for prediction of forage digestibility. J. Brit. Grassld. Soc. 33, 13-18.

Terry R.A., Osbourn D.F., Cammell S.B., Fenlon J.S., 1974. In vitro digestibility and the estimation of energy in herbage. Vaxtodling 28, 19-25.

Tilley J.M.A., Deriaz R.E., TERry R.A., 1960. The in vitro measurement of herbage digestibility and assessment of nutritive value. Proceedings of 8 th International Grassland Congress (Reading, England) pp. 533-537.

Tilley J.M.A., TERRY R.A., 1963. A two-stage technique for the in vitro digestion of forage crops. J. Brit. Grassld. Soc. 18, 104-111.

Tsutsumi M., AвE A., 1977. A comparison of results using five methods for the prediction of forage digestibility. J. Jap. Soc. Grassld. Sci. 23, 252-255.

Van Dyne G.M., Haug P.T., 1968. Oak Ridge National Laboratory, Oak Ridge, Tennessee, T.M., 1973. 73 pp.

Van Hellen R.W., Ellis W.C., 1977. Sample container porosities for rumen in situ studies. J. Anim. Sci. 44, 141. 
Van Der Koelen C.J., Van Es A.J.H., 1973. A comparison of some laboratory techniques for the estimation of the digestibility of the organic matter in forage samples. Neth. J. agric. Sci. 21, 199-205.

Van Der Koelen C.J., Dijkstra N.D., 1971. Digestibility determination in vitro as an aid in investigating the feeding value of roughage. Landbouwkundig Tijdschrift $\mathbf{8 3}$, 494-499.

Wilkins R.J., 1968. The digestibility of forage and its relationships to lignification. $J$. Austral. Inst. agric. Sci. 34, 221-222.

Witt N., Pedersen E.J.N., 1975. Comparison of various parameters for estimating the organic matter digestibility of grass crops. Tidsskrif für Flanteevl. 79, 266-272. 


\title{
Discussion
}

\author{
Chair : A. J. H. Van Es (The Netherlands)
}

Sir Kenneth BLAXTER $(U K)$. - We have been interested for quite a while in the so-called hemicellulose fraction. A large number of years ago, work on dried grasses showed that the main component of indigestibility was this particular fraction. Work by Dr. Baker and his colleagues at the Rowett shows that, of this mainly zylan fraction, its digestibility is largely determined not so much by the phenolic substitution, but the acetyl substitution on the hemicelluloses. This appears, in some respects, to be as good, if not better, a predictor of digestibility as a whole than the lignin. However, I would agree with Dr. Jarrige that lignin does appear to be the best predictor that we have but our colleagues, in the practical sphere of trying to advise, say the method is far too long. The correlation that we have got with Morrison-type lignin is quite reasonable, but it is measuring rather a different attribute of the lignin.

G. Alderman $(U K)$. - I would like to follow up on that, because some work we did about ten years ago, which we never published, on the Van Soest summative equation. confirmed exactly what Dr. Jarrige said. That is that we could get just as good a residual standard deviation by using acid detergent fibre alone, and we could save ourselves about one week's work per sample. We had no improvement with the summative equation. Turning to this problem of lignin; we had high hopes of the Morrison lignin technique to get us out of the difficulties of using 72 per cent sulphuric in the laboratory, which is not good for relatively low-grade staff. However, in the hands of our analysts, we could not get reproducibility between centres, and so we had to discard it. They could not identify the failure to get reproducibility in a ring test between centres. Consequently we are very interested in the cellulase technique which we have had on test in our laboratories, and we are developing regressions in that area which look quite promising. To confirm what Dr. Osbourn was saying, this problem of standardising the cellulase is one that we have got to tackle.

Sir Kenneth Blaxter. - Most of the commercial cellulases are very complex. Cellulase is rather large term. They include both endo- and exo-enzymes; they include carboxymethyl cellulases; they also include hemicellulases and a whole lot of other things. There is little doubt that you get different values from different bottles.

A.J.H. Van Es (The Netherlands). - Can you correct that if, at the same time, you use samples with known in vivo digestibility ?

Sir Kenneth Blaxter. - It means you have got to calibrate your systems every time.

G. Alderman. - We would see no difficulty in that because with the "in vitro" procedure, the Tilley and Terry, which we have run for a decade or more, we have always accepted the need to put four standard samples in to keep our errors down to the sort of figure that is workable ; deliberately spanned out to go from about 50 per cent digestibility, to 70 per cent. The results are always corrected on the standard samples.

A.J.H. VAN Es. - There is a difference here. In the "in vitro" you use rumen fiuid and, probably, most of the microbes which are present in the rumen. In the case of these cellulases we are using enzymes, and they are perhaps quite a different set of enzymes from those produced in the rumen. Is that true? Is that also one of the reasons why we have such variations from bottle to bottle, as Dr. Osbourn mentioned ?

D.F. Osbourn $(U K)$. - I cannot say. We haven't looked at it from that point of view at all.

Sir Kenneth BLAXTER. - I don't know very much about this. Dr. Wood and his colleagues are now looking at the cellulase complexes produced by ruminal bacteria. These appear to be associated with the so-called glycocalyx, which means a very, very close association has to be obtained between the micro-organisms and the material. This is what is happening in the "in vitro" system. With the fungal enzymes, these are excreted by the 
fungus into the medium. That means that you have got a rather different situation with regard to the proximity of the enzyme system to the material being broken down, with the liquid soluble enzyme compared with the bacteria where it is associated with a particle. But I don't really know what the answer to the question is.

A.J.H. Van Es. - Could that explain the difference between legumes and grass ?

Sir Kenneth Blaxter. - It could be related to the pectic substances, which seems to be far more likely. The special organisms which are concerned with pectinolosis in the rumen are a very distinct group of enzymes.

A.J.H. Van Es. - We have moved from one paper to the other, but it does not matter, they are quited interlinked.

\footnotetext{
A. Steg (The Netherlands). - Perhaps Dr Jarrige has come comments on the infra-red system ?
}

R. JARRIGE (France). - This problem will be discussed in the workshop. It is certainly interesting for large-scale screening, but for close predictions we have no experience of the technique due to lack of funds.

As for the other point on lignin. Lignin methods and forages are adaptations of lignin methods for wood, with the concentration of lignin up to 30 per cent, and where the protein and the soluble content is very low. When we are determining lignin in the forage plant we are measuring lignin in leaf blades, in the stems, in the flowers, etc., and the proportion of the different tissue on an histological basis. The structure of the cell walls is probably different. It is difficult to hope for any great improvements in this field. It is not surprising that the Morrison method, which was an adaptation of a timber method, did not work on every forage. Another disadvantage of the lignin method is that we are measuring a residue after a lot of treatment to standardise determination. It is not easy.

As for cellulase : ten years ago, when we worked on cellulase, it was a cellulase for digestive troubles. We obtained it from a firm but found that the second batch varied from the first. It may not have made any difference to the digestive troubles, but it was of little use in our work. It could be interesting to have a mixture, to have very impure cellulase.

T. Griffiths (Ireland). - - So far our speakers have considered the prediction of digestibility only. In the context of feeding standards, it is usually necessary to go further and attempt, for example, to predict metabolisable energy. Do they think that this is a possibility or a practicability?

D.F. Osbourn. - In a sense the movement onward is dependent upon the calorific value of the digestive organic matter. You can come close to that by considering the protein content or the starch content of your material. When you want to go from digested energy to ME, or if you want to go directly from DOM to ME, you are no longer concerned with what goes on in the laboratory, you are concerned with what goes on in the animal. Therefore, you must turn to your animal data to describe what factor you need to convert a digested energy to an ME. We can give you 0.82 as an approximation, but we have already seen that that is not always true ; factors vary from 0.9 to 0.78 . I do not see how anything you can do in the laboratory can help you take those steps or improve them. You can relate a measured ME to a laboratory procedure, but I doubt if that is fundamentally better than relating laboratory procedure to digestible organic matter.

G. Alderman. - I would like just to pursue that comment. Let us take the question of methane production. At the moment our Feed Evaluation Unit measure digestive energies ; we calculate methane from the Blaxter/Clapperton equation which, if I recall correctly, is concerned merely with organic matter. Now, I would have thought that with the type of analytical schemes we are now developing, we should be able to do rather better in predicting methane production. For example, is it really the case that we cannot calculate the expected methane production from sugar beet pulp as compared to cereals ? We have dramatically different contents of cellulose and starch between those two feeds and we observe the difference in methane production. So, back to you Dr. Osbourn ; is it really the case that methane production cannot be predicted from chemical analysis?

D.F. Osbourn. - Well, I think to some degree the answer is yes, but not by the same methodology that one is getting at cell wall degradability. 
G. Alderman. - Oh yes, I take the point that you do need the animal measurements to do it. I wonder if Sir Kenneth would like to comment on this point.

Sir Kenneth BlaXTER. - At the Rowett Feedstuffs Evaluation Unit we are measuring the faecal, urinary and methane losses of energy all the time. The objective is to be able to predict metabolisable energy measured at the maintenance level, from attributes of the feed. Simultaneously, the analyses of the feed are using the classical Weende analysis and what I think can now be called classical Van Soest analysis. A variety of other methods are also used, including "in vitro" digestibility measurements, cellulase digestibilities, and so on. At the moment I would say that for the prediction of metabolisable energy, the final value of the summation of all these, the best predictor that we have is lignin. It is very good. The problem is that in the application of this to advisory work, the method is too long. The only possibility is whether infra-red reflectance spectroscopy can give us a good measure of lignin, or something associated, so that the practical problem of advising farmers on the metabolisable energy value of their feeds could be solved by being able to do hundreds of them in an hour. This is where we want to get eventually.

A.J.H. VAN Es. - You made it very clear that this ME determination is made at the maintenance level. Now, very often we use the feedstuffs at other levels, or we do it in such a way that there is no longer a normal rumen fermentation. I think that we then have more problems in predicting the ME content of our digested energy or digested organic matter. If you feed high levels of corn together with corn silage even to beef cattle, does that give rise to a lot of problems?

Sir Kenneth BlaXter. - It is a secondary problem in my opinion. What we want is something which is a reproducible measurement, under standardised conditions. Then problems related to type of animal, level of feeding and so can be regarded as secondary problems. The first priority is the standardised measure. I think that generally people have now agreed to standardise the feeding level of their animals with regard to the primary measurement of metabolisable energy.

A.J.H. VAN Es. - I think Dr. Griffiths would like to have an answer to the secondary problem also.

Sir Kenneth Blaxter. - Well, take the methane equations that I developed with Clapperton. These do include effects of plane of nutrition, of level of feeding. Equally there is an enormous amount of information now available on the effects of level of feeding on apparent digestion. Just two hours ago we saw here a large comparative experiment with cattle, goats and sheep, to look at effects of level of feeding on digestion and how these change. However, you start off from the base line of one standardised measurement.

T. Griffiths. - One thing that struck me about the work at the Rowett Feed Evaluation Unit was that if you took a wide range of barleys for example, you had non-significant differences between the samples. I believe this was true for the major cereals, but not for wheat offals. With regard to the practical application, would it not be better to look at materials like silage and hay and categorise them, to attempt to consider silages in three categories and apply tables as you can in the case of concentrates.

Sir Kenneth Blaxter. - The basis idea of the Feed Evaluation Unit was to determine metabolisable energy values in the animals and then state which attributes of feed can be used to predict these values. If you can make a group, so much the better, but we have not been able to classify them yet.

H. BICKEL (Switzerland). - Just to change the approach somewhat; we know that in other fields than ours the microbiologists have made quite good progress in the continuous multiplying of standardised mixed microbial populations. I wonder if this could be applied to rumen microbial populations to make estimations, rather than by enzymatic methods.

D.F. Osbourn. - I don't know that anyone has tried it with that objective. I suppose Den Braver has got a long way towards it with his technique. Presumably he could get a great mass of rumen liquor from a slaughterhouse and then freeze it. He has shown already that the activity has remained constant on frozen rumen liquor with his system where he goes in for a 96 hour digestion and a very dilute inoculation.

H. BICKEL. - I thought it was "in vitro"... 
D.F. Osbourn. - It is an "in vitro" system.

H. Bickel. - No, but the multiplying of the microbial populations "in vitro"...

D.F. OsbourN. - I think it would be very difficult to maintain a population.

H. Bickel. - Yes, that is the question I wanted to ask - I realise it is difficult.

Sir Kenneth BLAXTER. - Equally, I would say that it is extremely difficult to maintain a single organism without it mutating. We had this problem with maintaining our cellulolytic organisms - they mutate and lose certain aspects of their cellulolytic activity.

A.J.H. VAN Es. - We tried to freeze rumen fluid and store it ; it was less active after two months. Perhaps they have had better experience in Sweden, I don't know.

J. L'EsTRANGE (Ireland). - I would like just to extend the discussion from the prediction of $\mathrm{ME}$ value to the prediction of intake. Dr. Jarrige, could you comment on this because in your new system you are, in fact, putting down predicted intake values. Do you have any way of measuring what these intake values might be ?

R. JARRIGE. - The paper was limited to digestible protein and energy values, but there are many relationships between chemical composition and intake. Dr. Demarquilly can give you the relationship measured on sheep for protein and crude fibre content. It could probably be improved with the determination of some other constituents. You can also have better relationships between intake and some enzymatic methods, or some physical methods such as the resistance of forage to grinding, and so on. Clearly there are some possibilities - probably combining intake and energy values to obtain the whole feeding value of the forage is quite feasible from chemical composition, maybe with a better relationship because generally the two parameters, intake and energy value, go together - even crude fibre could be a good predictor. 